\title{
Pengaruh Permainan Memancing Ikan terhadap Kemampuan Berhitung Anak Usia 5-6 Tahun Di PAUD SPS Mutiara Belia Pekanbaru
}

\author{
Witrimus $^{1)}$, Reswita ${ }^{2)}$ \\ ${ }^{1}$ Universitas Lancang Kuning \\ email:witrimus@gmail.com \\ ${ }^{2}$ Universitas Lancang Kuning \\ email: reswita@unilak.ac.id
}

\begin{abstract}
Abstrak
Penelitian ini bertujuan untuk mengetahui pengaruh permainan memancing ikan terhadap kemampuan berhitung anak usia 5-6 tahun di PAUD SPS Mutiara Belia Pekanbaru. Hipotesis penelitian ini adalah terdapat pengaruh yang signifikan dalam penggunaan permainan memancing ikan terhadap kemampuan berhitung anak. Penelitian ini menggunakan pendekatan Kuantitatif yang berbentuk Quasy Eksperimen. Populasi penelitian adalah anak PAUD SPS Mutiara Belia Pekanbaru yang berusia 5-6 tahun yang berjumlah 36 orang yang terbagi kedalam 2 kelompok belajar dan teknik pengambilan sampelnya adalah Purposive Sampling, yaitu kelas B1 dan kelas B2 masing-masing berjumlah 15 orang anak. Teknik pengumpulan data yang digunakan adalah tes / unjuk kerja, berupa penyataan 7 butir pernyataan dan alat pengumpulan data digunakan lembar pernyataan. Kemudian data diolah dengan uji perbedaan (uji independen sample t-test) menggunakan Program Software SPSS Versi 21.0 for Windows. Berdasarkan analisa data, diperoleh rata-rata hasil tes / unjuk kerja setelah perlakuan (post-test) kelas eksperimen (B1) adalah 82,13 dan SD 9,855 sedangkan pada kelas kontrol (B2) adalah 74,47 dan SD sebesar 8,114. Pada pengujian hipotesis diperoleh nilai Sig. (2-tailed) sebesar 0,027 lebih kecil dari taraf signifikansi $\alpha=0,05$. Maka dapat disimpulkan penggunaan permainan memancing ikan berpengaruh terhadap kemampuan berhitung anak usia 5-6 tahun di PAUD SPS Mutiara Belia Pekanbaru.
\end{abstract}

Kata Kunci: Permainan Memancing Ikan, Kemampuan Berhitung, Anak Usia 5-6 Tahun 


\section{Abstract}

This study aims to determine the effect of fishing game on the ability to count children aged 5-6 years in PAUD SPS Mutiara Belia Pekanbaru. The research hypothesis is that there is a significant influence on the use of fishing games on children's numeracy skills. This study uses a quantitative approach in the form of Quasy Experiments. The study population was children of PAUD SPS Mutiara Belia Pekanbaru who were aged 5-6 years totaling 30 people divided into 2 study groups and the sampling technique was Purposive Sampling, namely class B1 and class B2 each of 15 children. The data collection technique used is the test / performance, in the form of revelation of 7 items statement and data collection tool used statement sheet. Then the data is processed by a difference test (independent sample t-test) using the SPSS Version 21.0 for Windows Software Program. Based on the data analysis, the average test results / performance after the experimental class (post-test) treatment (B1) were 82.13 and SD 9.855 while the control class (B2) was 74.47 and SD was 8.114. In testing the hypothesis obtained the value of Sig. (2-tailed) of 0.027 smaller than the significance level $\alpha=0.05$. So it can be concluded that the use of fishing games influences the ability to count children aged 5-6 years in PAUD SPS Mutiara Belia Pekanbaru.

\section{Keywords: Game of Fishing, Counting Ability, Children Aged 5-6 Years}

\section{PENDAHULUAN}

Anak usia dini adalah seorang anak yang usianya belum memasuki suatu lembaga pendidikan formal seperti sekolah dasar (SD) dan biasanya mereka tetap tinggal di rumah atau mengikuti kegiatan dalam bentuk berbagai lembaga pendidikan prasekolah, seperti kelompok bermain, taman kanak-kanak, atau taman penitipan anak. Anak usia dini adalah anak yang berusia 0-8 tahun. Sedangkan pada hakekatnya anak usia dini, menurut Augusta (2012), sebagaimana dikutip oleh Hasnida (2014 : 167), adalah individu yang unik dimana ia memiliki pola pertumbuhan dan perkembangan dalam aspek fisik, kognitif, sosial emosional, kreativitas, bahasa dan komunikasi yang khusus yang sesuai dengan tahapan yang sedang dilalui oleh anak tersebut.

Menurut Melati (2012 : 43) bahwa anak usia dini adalah anak yang baru dilahirkan sampai usia 6 tahun. Usia ini merupakan usia yang sangat menentukan dalam pembentukan karakter dan kepribadian anak. Usia dini merupakan usia dimana anak mengalami pertumbuhan dan perkembangan yang pesat. Anak usia dini memiliki karakteristik yang khas baik secara fisik, sosial, emosi, kognitif, dan spiritual yang berhubungan erat satu sama lain. Masa dini merupakan masa paling penting untuk sepanjang hidupnya, sebab masa usia dini adalah masa pembentukan pondasi dan dasar kepribadian yang akan menentukan pengalaman anak selanjutnya. Menurut Hasnida (2014 : 180-181), mengatakan bahwa karakteristik anak usia dini antara lain : 1) memiliki rasa ingin tahu yang besar, 2) merupakan pribadi yang unik, 3) suka berfantasi dan berimajinasi, $\quad 4)$ masa paling potensi untuk belajar, 5) menunjukkan sikap egosentris, $\quad 6)$ memiliki rentang daya konsentrasi yang pendek, 
7) dan sebagai bagian dari makhluk sosial

Berdasarkan beberapa pendapat diatas, dapat disimpulkan bahwa anak usia dini merupakan individu yang memiliki karakteristik yang berbeda satu dengan lainnya, yang berusia sekitaran 0-6 tahun yang sedang mengalami proses pertumbuhan dan perkembangan yang luar biasa sehingga memunculkan berbagai keunikan pada dirinya, dan pada tahap inilah, masa yang tepat untuk menanamkan nilainilai kebaikan yang nantinya diharapkan dapat membentuk kepribadiannya.

Pendidikan anak usia dini (PAUD) berdasarkan Permendikbud Nomor 146 Tahun 2014 Pasal 1 tentang Kurikulum 2013 dalam Susanto (2017 : 14), menyatakan bahwa : Pendidikan anak usia dini merupakan jenjang pendidikan sebelum jenjang pendidikan dasar sebagai suatu upaya pembinaan yang ditujukan bagi anak sejak lahir sampai dengan usia enam tahun. Dilakukan melalui pemberian rangsangan pendidikan untuk membantu pertumbuhan dan perkembangan jasmani serta rohani agar anak memiliki kesiapan dalam memasuki pendidikan lebih lanjut.

Pendidikan pada anak usia dini pada dasarnya menurut Sujiono (2012 : 7), meliputi seluruh upaya dan tindakan yang dilakukan oleh pendidik dan orang tua dalam proses perawatan, pengasuhan, dan pendidikan pada anak dengan menciptakan aura dan lingkungan dimana anak dapat mengeksplorasi pengalaman yang memberikan kesempatan kepadanya untuk mengetahui dan memahami pengalaman belajar yang diperolehnya dari lingkungan, melalui cara mengamati, meniru, dan bereksperimen yang berlangsung secara berulang-ulang dan melibatkan seluruh potensi dan kecerdasan anak.

Proses pendidikan pada anak usia dini dikondisikan dalam suasana belajar aktif, kreatif, dan menyenangkan lewat berbagai permainan. Dalam pelaksanaan pendidikan anak usia dini menurut Susilo (2016 : 32-34), menggunakan prinsip-prinsip sebagai berikut : 1) berorientasi pada kebutuhan anak, 2) sesuai dengan perkembangan anak, 3) mengembangkan kecerdasan anak, 4) belajar melalui bermain, 5) belajar dari kongkret ke abstrak, sederhana ke kompleks, gerakan ke verbal, dan dari sendiri ke sosial, 6) anak sebagai pembelajar aktif, 7) anak belajar melalui interaksi sosial dengan orang dewasa, dan teman sebaya di lingkungannya, 8) menggunakan lingkungan yang kondusif, 9) merangsang kreativitas dan inovasi, 10) mengembangkan kecakapan hidup, 11) memanfaatkan potensi lingkungan, 12) sesuai dengan kondisi sosial budaya, 13) stimulasi secara terpadu atau holistik, 14) dilaksanakan secara bertahap dan berulang, 15) dan pemanfaatan teknologi informasi.

Fungsi utama Pendidikan anak usia dini (PAUD) menurut Musbikin (2010 : 47), yaitu mengembangkan semua aspek perkembangan anak, meliputi perkembangan kognitif, bahasa, fisik (motorik kasar dan halus), sosial, dan emosional. Serta PAUD juga berfungsi untuk membina, menumbuhkan, dan mengembangkan seluruh potensi anak usia dini secara optimal sehingga terbentuk perilaku dan kemampuan dasar sesuai dengan tahap perkembangannya agar memiliki kesiapan untuk memasuki pendidikan selanjutnya . 
Salah satu kemampuan yang perlu dikembangkan pada anak usia dini yaitu kemampuan berhitung diman kemampuan ini masuk dalam perkembangan kognitif. Kemampuan berhitung sangat diperlukan untuk mengembangkan pengetahuan anak tentang angka, bilangan, penjumlahan dan pengurangan. Selain itu, berhitung juga merupakan dasar bagi perkembangan kemampuan matematika anak untuk mengikuti pendidikan selanjutnya (Suryana, 2016 : 108).

Kecerdasan berhitung anak ditandai dengan kemampuannya untuk berinteraksi dengan angka-angka dan bilangan, berpikir logis dan ilmiah serta adanya konsistensi dalam pemikiran. Anak yang cerdas belajar berhitungnya secara logika matematikanya akan tertarik dengan bilangan dan angka. Anak dapat mempelajari berhitung melalui konsep matematika, yaitu melalui berhitung benda konkret, menghubungkan jumlah dengan lambang bilangan, dan mengembangkan konsep menambah serta mengurang (Suryana, 2016 : 108).

Karakteristik anak yang sudah mengalami perkembangan dalam berhitung menurut Depdiknas (2007 : 12), dikutip dari Sukmawati (2015: 17), antara lain :

1. Secara spontan telah menunjukkan ketertarikan pada aktivitas permainan berhitung.

2. Anak mulai menyebut urutan bilangan tanpa pemahaman.

3. Anak mulai menghitung bendabenda dan peristiwa yang ada disekitarnya.

4. Anak mulai menjumlahkan atau mengurangi angka dan benda-benda yang ada disekitarnya tanpa disengaja.
Kemampuan berhitung adalah kemampuan yang dimiliki setiap anak untuk mengembangkan kemampuannya, karakteristik perkembangan dimulai dari lingkungan yang terdekat dengan dirinya, sejalan dengan perkembangan kemampuannya anak dapat meningkat ketahap pengertian jumlah, yaitu berhubungan dengan jumlah dan pengurangan. Mengingat begitu pentingnya kemampuan berhitung bagi manusia, maka kemampuan berhitung ini perlu diajarkan sejak dini dengan berbagai media dan metode yang tepat, jangan sampai dapat merusak pola perkembangan anak. Apabila anak belajar berhitung melalui cara yang sederhana, namun tepat dan mengena serta dilakukan secara konsisten dan kontinu dalam suasana yang kondusif dan menyenangkan, maka otak anak akan terlatih untuk terus berkembang sehingga anak dapat menguasai, dan bahkan menyenangi pembelajaran berhitung tersebut. Oleh karena itu perlu media dan metode yang tepat dalam pembelajaran berhitung ini, karena anak sampai usia 5 tahun belum dapat melakukan kegiatan berhitung dengan sesungguhnya (berhitung dengan bilangan abstrak). Masa ini anak berada pada tahap berhitung permulaan, yaitu anak berhitung dengan bendabenda dari lingkungan yang terdekatnya, dan situasi permainan yang menyenangkan, tujuannya anak mampu bekerja dengan bilangan. Baru pada usia enam tahun, anak mulai berkembang konsep bilangan sampai pada peningkatan ke tahap pengertian mengenai jumlah, konsep jumlah berhubungan dengan penjumlahan dan pengurangan, semakin tinggi kemampuan anak, maka akan semakin mudah untuk memecahkan masalah yang lebih rumit (Susanto, 2011 : 9899). 
Berbagai cara dapat dilakukan oleh guru dan orang tua untuk mengembangkan atau meningkatkan kemampuan berhitung permulaan, kemampuan berhitung merupakan kemampuan untuk menggunakan keterampilan berhitung, tahapan yang dapat dilakukan untuk membantu mempercepat penguasaan berhitung melalui jalur matematika, misalnya tahap penguasaan konsep, tahap transisi, dan tahap pengenalan lambang. Menurut Depdiknas (2000 : 7-8), dikutip dari Susanto (2011 : 99-100), mengemukakan bahwa : 1) tahap penguasaan konsep, dimulai dengan mengenalkan konsep atau pengertian tentang sesuatu dengan menggunakan benda-benda yang nyata, seperti pengenalan warna, bentuk, dan menghitung bilangan, 2) tahap transisi, merupakan peralihan dari pemahaman secara konkret dengan menggunakan benda-benda nyata menuju ke arah pemahaman secara abstrak, 3) tahap pengenalan lambang, adalah dimana setelah anak memahami sesuatu secara abstrak, maka anak dapat dikenalkan pada tingkat penguasaan terhadap konsep bilangan dengan cara meminta anak melakukan proses penjumlahan dan pengurangan melalui penyelesaian soal.

Permainan memancing ikan merupakan salah satu aktivitas yang menyenangkan sekaligus penuh tantangan. Permainan memancing ikan memberikan kesenangan tersendiri bagi anak-anak, sekaligus memberikan pengetahuan tentang berbagai jenis ikan, terutama ikan yang berhasil mereka pancing. Selain itu juga dapat melatih kemampuan motorik, kognitif, dan emosional. Permainan ini juga akan membuat anak merasakan senang dan gembira yang tak ternilai harganya saat berhasil menangkap ikan (Nurjatmika, 2012 : 89).

Menurut Triharso (2013 : 59), mengatakan bahwa permainan memancing ikan merupakan permainan yang sangat disukai atau disenangi oleh anak-anak, dan permainan memancing ikan juga mengajarkan kepada anak untuk dapat berkonsentrasi, melatih kesabaran anak, sekaligus dapat mengajarkan konsep berhitung kepada anak.

Berdasarkan pendapat diatas, dapat disimpulkan bahwa permainan memancing ikan adalah merupakan salah satu aktivitas yang dapat menyenangkan sekaligus penuh tantangan, serta dapat melatih kemampuan motorik, kognitif dan emosional anak.

Adapun langkah-langkah dalam permainan memancing ikan ini adalah :

1. Menyiapkan alat dan bahan yang akan digunakan. Alat dan bahan tersebut adalah : alat pancing bermagnet, kerancang kecil tempat ikan yang telah ditangkap, kolam ikan dari box contener besar dan ikan yang dibuat dari kertas tebal warna warni yang telah digambar bermacam-macam jenis ikan yang ditengah badannya diberi lingkaran dan didalam lingkaran tersebut ditulis angka 1-10 dan setelah itu diliminating dan digunting mengikuti lekukan ikan kemudian didekat mulut ikan dilobangi menggunakan pelobang kertas dan diberi klip kertas. 

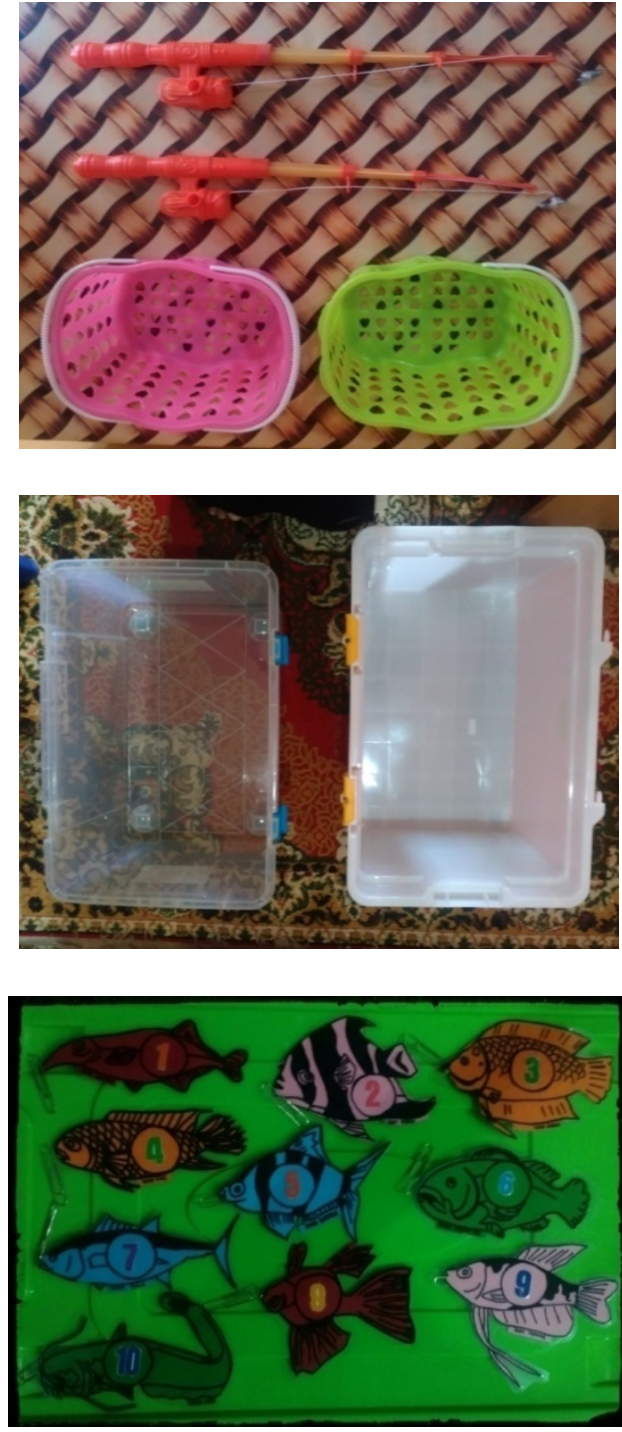

2. Letakan ikan dalam box contener besar ( sebagai kolamnya).

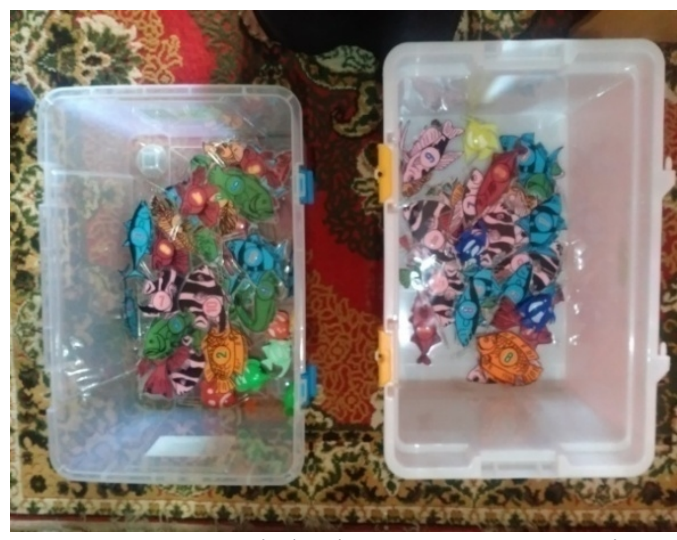

3. Guru menjelaskan cara permainan dan aturan permainan.

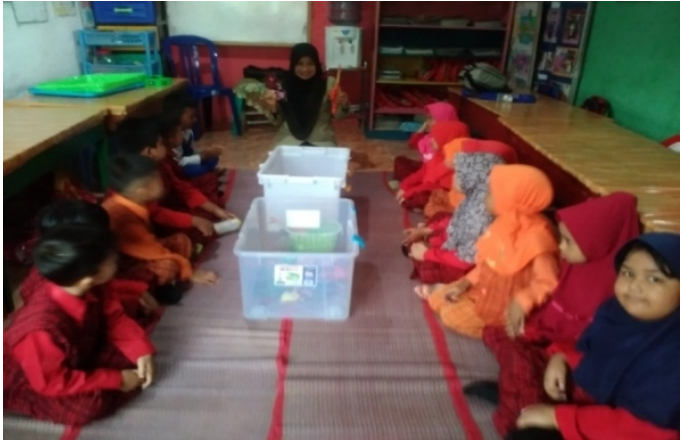

4. Minta anak untuk mencoba mengail ikan dengan alat pancing yang telah disediakan.

5. Setiap anak mengambil satu ikan menggunakan alat pancing.

6. Tarik ikan kemudian letakkan ke tempat yang sudah disediakan.

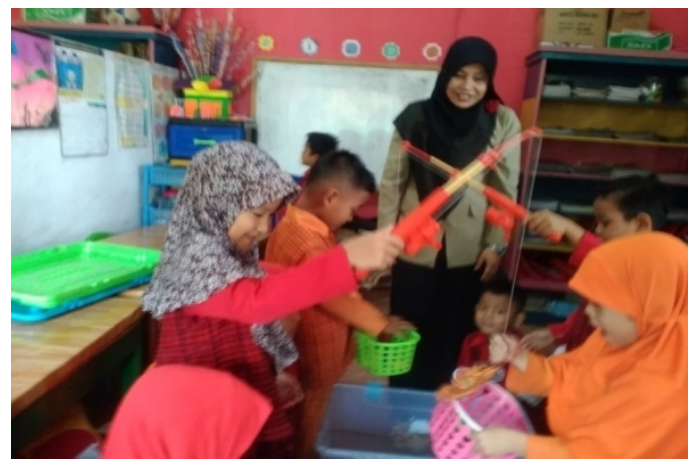

7. Jika anak mengetahui angka yang ada pada badan ikan yang sudah didapat maka angka tersebut termasuk dalam hasil tangkapan ikan. Jika anak tersebut tidak mengetahui, maka hasil ikan (angka) yang dikumpulkan dihitung sebagai hasil tangkapan ikan yang lolos.

8. Setiap anak mendapatkan giliran minimal dua kesempatan. Jika anak-anak sudah terbiasa dengan permainan ini, kegiatan permainan dapat dilanjutkan dengan kompetisi secara individu dan kelompok.

Berdasarkan hasil observasi di PAUD SPS Mutiara Belia Pekanbaru peneliti menemukan fenomena bahwa dalam mengembangkan kemampuan 
berhitung pada anak, seperti dalam hal mengenal angka, pada umumnya anak hafal angka 1 sampai 10, tetapi mereka mengalami kesulitan ketika dihadapkan pada kegiatan berhitung yang sesungguhnya seperti dalam hal mengurut angka, mungkin mereka mengerti 1-2-3, tetapi tidak dapat membayangkan 6-7-8, dan menyebut angka bila diperlihatkan lambang bilangan, serta menyebutkan jumlah benda dengan cara menghitung, ditambah lagi dalam memberikan pembelajaran guru masih menggunakan majalah, buku, kalender angka dan permainan yang diajarkan oleh guru terlihat kurang menarik untuk mengembangkan kemampuan berhitung pada anak. Dan metode yang digunakan guru dalam mengembangkan kemampuan berhitung pada anak biasanya menggunakan metode bercerita, metode bercakap-cakap, metode tanya jawab, dan metode pemberian tugas. Selain itu, guru masih menggunakan metode pembelajaran konvensional yaitu metode pembelajaran lebih banyak menggunakan ceramah. Akibatnya berdampak terhadap kemampuan berhitung anak. Dimana pembelajaran terasa membosankan bagi anak, konsentrasi anak terhadap pembelajaran yang diberikan guru sangat pendek, sehingga anak sering mengalihkan perhatiannya dengan bermain. Maka dari itu peneliti memandang perlu diadakannya perubahan, yang harus dilakukan guru untuk membantu anak dalam memahami konsep berhitung yang menarik dan mudah dipahami anak yaitu dengan menggunakan permainan memancing ikan.

Permainan Memancing ikan dapat mengkombinasikan beberapa aktivitas berhitung seperti latihan mengenal angka, menyebutkan lambang bilangan
1-10, menggunakan lambang bilangan untuk menjumlah, mencocokkan bilangan dengan lambang bilangan dan lain sebagainya. Oleh karena itu peneliti beranggapan permainan memancing ikan merupakan salah satu permainan yang sangat cocok untuk melatih kemampuan berhitung pada anak.

\section{METODE}

Jenis penelitian ini adalah kuantitatif dengan metode eksperimen dalam bentuk quasi experimental design/ experimen semu (nonequivalent control group design). Seperti menurut Sugiyono (2014 : 72), mengatakan bahwa metode penelitian eksperimen dapat diartikan sebagai metode penelitian yang digunakan untuk mencari pengaruh perlakuan tertentu terhadap yang lain dalam kondisi yang terkendalikan.

Peneliti melakukan penelitian di PAUD SPS Mutiara Belia Pekanbaru, selama 2 bulan terhitung dari bulan Oktober sampai dengan November 2018. Sampel dalam penelitian ini adalah anak kelas B1 dan kelas B2. Dimana kelas B1 dijadikan kelas eksperimen dan kelas B2 dijadikan kelas kontrol.

Teknik yang digunakan dalam pengumpulan data pada penelitian ini adalah tes / unjuk kerja yang digunakan untuk melihat pengaruh permainan memancing ikan terhadap kemampuan berhitung anak usia 5-6 tahun

Teknik analisis data yang digunakan dalam penelitian ini adalah membandingkan perbedaan dari dua rata-rata nilai, sehingga dilakukan dengan uji $t$ (t-tes). Namun sebelum itu, 
terlebih dahulu melakukan uji normalitas dan uji homogenitas.

\section{HASIL DAN PEMBAHASAN}

Berdasarkan hasil tes / unjuk kerja anak sebelum perlakuan (Pre-Test) kemampuan berhitung anak pada kelas eksperimen (B1) dan kelas kontrol (B2) diperoleh angka rata-rata kelas eksperimen (B1) adalah 62,80 dan angka rata-rata kelas kontrol (B2) adalah 61,40. Dan berdasarkan hasil analisis data yang dilakukan menggunakan Program Software SPSS Versi 21.0 for Windows bahwa Nilai Sig. (2-tailed) sebesar $0,600>0,05$ (nilai signifikan). Maka dapat dikatakan bahwa hipotesis $\mathrm{H}_{\mathrm{o}}$ diterima dan $\mathrm{H}_{\mathrm{a}}$ ditolak. Jadi dapat disimpulkan bahwa hasil analisis data yang dilakukan menggunakan Program Software SPSS Versi 21.0 for Windows tidak terdapat perbedaan yang signifikan antara kemampuan berhitung anak di kelas eksperimen (B1) dan kelas kontrol (B2). Begitu juga dengan hasil analisis data yang dilakukan menggunakan manual, bahwa $t_{\text {hitung sebesar } 0,512 \text { dibandingkan }}$ dengan $\alpha 0,05\left(t_{\text {tabel }}=2,048\right)$ dengan derajat kebebasan dk $\left(\mathrm{N}_{1}-1\right)+\left(\mathrm{N}_{2}-1\right)$ $=28$. Dengan demikian $t_{\text {hitung }}<t_{\text {tabel }}$, yaitu $0,512<2,048$, maka dapat dikatakan bahwa hipotesis $\mathrm{H}_{\mathrm{a}}$ ditolak atau $\mathrm{H}_{\mathrm{o}}$ diterima. Jadi dapat disimpulkan bahwa hasil analisis data yang dilakukan menggunakan manual juga tidak terdapat perbedaan yang signifikan antara kemampuan berhitung anak di kelas eksperimen (B1) dan kelas kontrol (B2).

Kemudian, berdasarkan hasil tes / unjuk kerja anak setelah perlakuan (Post-Test) kemampuan berhitung anak pada kelas eksperimen (B1) dengan menggunakan permainan memancing ikan dan kelas kontrol (B2) menggunakan permainan yang biasa dilakukan disekolah PAUD SPS Mutiara Belia Pekanbaru saat pembelajaran berhitung (permainan berhitung dengan jari) diperoleh angka rata-rata kelas eksperimen (B1) adalah 82,13 dan angka rata-rata kelas kontrol (B2) adalah 74,47. Dan berdasarkan hasil analisis data yang dilakukan menggunakan Program Software SPSS Versi 21.0 for Windows bahwa Nilai Sig. (2-tailed) sebesar $0,027<0,05$ (nilai signifikan). Maka dapat dikatakan bahwa hipotesis $\mathrm{H}_{\mathrm{o}}$ ditolak dan $\mathrm{H}_{\mathrm{a}}$ diterima. Jadi dapat disimpulkan bahwa hasil analisis data yang dilakukan menggunakan Program Software SPSS Versi 21.0 for Windows terdapat perbedaan yang signifikan antara kemampuan berhitung anak di kelas eksperimen (B1) menggunakan permainan memancing ikan dengan kelas kontrol (B2) menggunakan permainan yang biasa dilakukan disekolah PAUD SPS Mutiara Belia Pekanbaru saat pembelajaran berhitung (permainan berhitung dengan jari). Begitu juga dengan hasil analisis data yang dilakukan menggunakan manual,

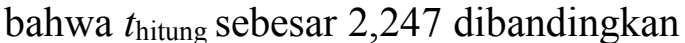
dengan $\alpha$ 0,05 $\left(t_{\text {tabel }}=2,048\right)$ dengan derajat kebebasan $\mathrm{dk}\left(\mathrm{N}_{1}-1\right)+\left(\mathrm{N}_{2}-1\right)$ $=28$. Dengan demikian $t_{\text {hitung }}>t_{\text {tabel}}$, yaitu 2,247 > 2,048, maka dapat dikatakan bahwa hipotesis $\mathrm{H}_{\mathrm{a}}$ diterima atau $\mathrm{H}_{\mathrm{o}}$ ditolak. Jadi dapat disimpulkan bahwa hasil analisis data yang dilakukan menggunakan manual juga terdapat perbedaan yang signifikan antara kemampuan berhitung anak di kelas eksperimen (B1) menggunakan permainan memancing ikan dengan kelas kontrol (B2) menggunakan permainan yang biasa dilakukan disekolah PAUD SPS Mutiara Belia Pekanbaru saat pembelajaran berhitung (permainan berhitung dengan jari). 


\section{KESIMPULAN}

Berdasarkan hasil penelitian dan pembahasan dapat ditarik kesimpulan bahwa terdapat Pengaruh Permainan Memancing Ikan terhadap Kemampuan Berhitung Anak Usia 5-6 Tahun di PAUD SPS Mutiara Belia Pekanbaru dengan nilai rata-rata yang diperoleh dari kelas eksperimen (B1) 82,13 lebih tinggi dibandingkan dengan kelas kontrol (B2) 74,47. Berdasarkan hasil uji hipotesis menggunakan Program Software SPSS Versi 21.0 for Windows diperoleh nilai Sig. (2-tailed) sebesar $0,027<0,05$ (nilai signifikan). Maka dapat dikatakan bahwa hipotesis $\mathrm{H}_{\mathrm{o}}$ ditolak dan $\mathrm{H}_{\mathrm{a}}$ diterima. Dengan kata lain terdapat perbedaan/pengaruh yang signifikan antara kemampuan berhitung anak di kelas eksperimen (B1) menggunakan permainan memancing ikan dengan kelas kontrol (B2) menggunakan permainan yang biasa dilakukan disekolah PAUD SPS Mutiara Belia Pekanbaru saat pembelajaran berhitung (permainan berhitung dengan jari).

\section{DAFTAR PUSTAKA}

[1] Anggelina, Pitri. (2015). Efektivitas Permainan Petualangan Angka Terhadap Kemampuan Berhitung Anak di Taman Kanak-Kanak Islam Mutiara Al Madani Sungai Penuh Jambi (Skripsi). Program Studi Pendidikan Anak Usia Dini. Fakultas Ilmu Pendidikan. Universitas Negeri Padang. Padang.

[2] Anggreani, Chresty. (2013). Upaya Meningkatkan Kemampuan Berhitung Dengan Menggunakan Metode Bermain Melalui Media Ikan Di Akuarium Pada Anak Kelompok B1 TK IT IQRA Kota Bengkulu (Skripsi). Program Studi Pendidikan Anak Usia Dini.
Fakultas Keguruan Dan Ilmu Pendidikan. Universitas Bengkulu. Bengkulu.

[3] Desfita, Megi. (2016). Efektivitas Game Interaktif Bobby Bola Dan Nano Terhadap Peningkatan Kemampuan Berhitung Anak Di Taman Kanak-Kanak Negeri Pembina Bukittinggi (Skripsi). Program Studi Pendidikan Anak Usia Dini. Fakultas Ilmu Pendidikan. Universitas Negeri Padang. Padang.

[4] Fadlillah, Muhammad. (2014). Desain Pembelajaran PAUD. Jogjakarta : Ar-Ruzz Media.

[5] Hasnida. (2014). Analisa Kebutuhan Anak Usia Dini. Jakarta : PT. Luxima Metro Media.

[6] Hildayani, Rini. (2011). Psikologi Perkembangan Anak. Jakarta : Universitas Terbuka.

[7] Herawati, Netti. (2005). Buku Pendidik Pendidikan Anak Usia Dini Usia 3-4 Tahun. Pekanbaru : Quantum.

[8] Melati, Risang. (2012). Kiat Sukses Menjadi Guru PAUD yang Disukai Anak-anak. Yogyakarta : Araska.

[9] Mohandas, Ramon. (2015). Buku Panduan Pendidik Kurikulum 2013 PAUD Anak Usia 4-5 Tahun. Jakarta : Pusat Kurikulum dan Pembukuan, Badan Penelitian dan Pengembangan Kementerian Pendidikan dan Kebudayaan.

[10] Musbikin, Imam. (2010). Buku Pintar PAUD. Jogjakarta : Laksana. 
[11] Mutiah, Diana. (2010). Psikologi Bermain Anak Usia Dini. Jakarta : Kencana Prenada Media Group.

[12] Putri, Rahmita Yulia. (2016). Pengaruh Game Educative Gcompris Terhadap Kemampuan Membaca Anak di PAUD Terpadu Mutiara Bunda Kabupaten Lima Puluh Kota (Skripsi). Program Studi Pendidikan Guru Pendidikan Anak Usia Dini. Fakultas Ilmu Pendidikan. Universitas Negeri Padang. Padang.

[13] Rahmawati. (2015). Pengaruh Permainan Bowling Terhadap Kemampuan Berhitung Permulaan Anak Usia 5-6 Tahun di TK Pembina Palembang (Skripsi). Program Studi Pendidikan Guru Pendidikan Anak Usia Dini. Fakultas Keguruan dan Ilmu Pendidikan. Universitas Sriwijaya. Indralaya.

[14] Sugiyono. (2014). Metode Penelitian Kuantitatif Kualitatif Dan $R \& D$. Bandung : Alfabeta.

[15] Susanto, Ahmad. (2011). Perkembangan Anak Usia Dini : Pengantar Dalam Berbagai Aspeknya. Jakarta : Kencana.

[16] Susilo, Setiadi. (2016). Pedoman Penyelenggaraan PAUD. Jakarta : Bee Media Pustaka. 